\title{
Standing Tall: the evolution of habitable room height limits in New Zealand building controls
}

Nigel Isaacs, School of Architecture, Victoria University of Wellington

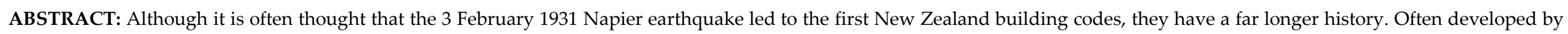

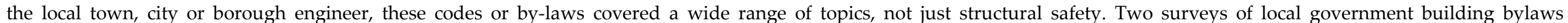

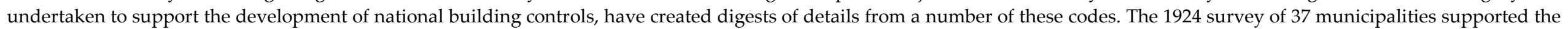

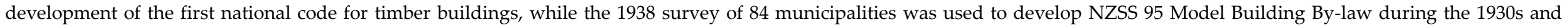

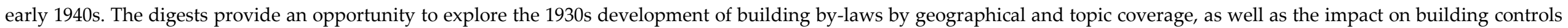
since that time.

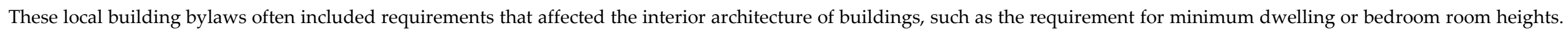

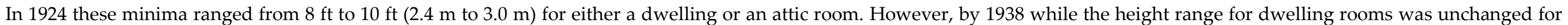

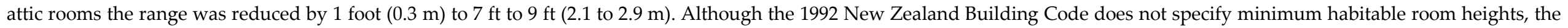
House Improvement Regulations 1947 are still in force. These initially set the habitable room height requirement to $2.1 \mathrm{~m}$, increasing in 1975 to $2.4 \mathrm{~m}$.

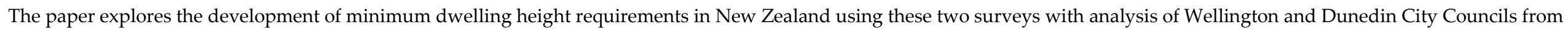

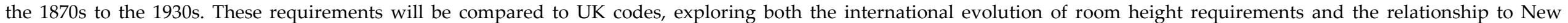
Zealand.

\section{Introduction}

An 1876 presentation to the Architectural Association listed six ways in which the builder through faulty erection of a building could damage their neighbours:

1. He may build so badly, or so neglect to maintain, that the building may fall down. Security must, therefore, be insured.

2. He may build so that his premises may be liable to catch fire, and to communicate fire to the adjoining premises. Protection against fire must, therefore, be insured.

3. He may grievously annoy his next-door neighbour by himself building in an unreasonable way, or by hindering his neighbour when he wants to build.
Rights of adjoining owners must, therefore, be defined.

4. He may build a house that is thoroughly unhealthy.

5. He may interfere with his neighbour's enjoyment of the street in which they both stand.

6. He may cut off his neighbour's light and air. ${ }^{1}$

The focus of this paper relates to part of the fourth item - limiting aspects of a house which may lead to a worsening of the occupants' health - through exploring the development of requirements for minimum habitable room heights. For purposes of this

${ }^{1}$ Smith "The Metropolitan Building Act" p 279. paper, no attempt has been to standardise the meaning of the term "habitable" which is taken as defined in the specific code and may as a consequence differ between codes and/or locations.

\section{Conversion}

As the period covered by this paper is centred on the 1930s, measurements are given in the original units - feet and inches. The Housing Improvement Regulations 1947 were converted to metric units when amended in 1975 e.g. $5 \mathrm{ft}=1.5 \mathrm{~m} ; 7 \mathrm{ft}=2.1 \mathrm{~m} ; 8 \mathrm{ft}=2.4 \mathrm{~m}$. 


\section{In the beginning}

The legislation which followed the 1666 Great Fire of London provides the earliest example of a requirement for minimum room heights. The 1666 "Act for rebuilding the City of London" firstly divided housing into four types based on location, and then for those of lessor importance allocated minimum habitable room heights, as given in Table 1. The more prestigious the dwelling the higher the room heights, although for the "Fourth and largest sort of Mansion houses for Citizens or other persons of extraordinary quality" there were no minimum height(s) but the building could be no more than four storeys. ${ }^{2}$ No reasons are provided for the basis for the heights, although they probably related to issues of ventilation and health. Room heights were not included in the following 1774 Building Act. $^{3}$

It was not until the $1840 \mathrm{~s}$ that the issue of room heights again entered building legislation. The 1844 Metropolitan Building Act set a minimum room height of $7 \mathrm{ft}(2.1 \mathrm{~m})$,

${ }^{2}$ Great Britain Parliament House of Commons An Act for Rebuilding the City of London 1666 (18 \& 19 Car II c8) p 605.

${ }^{3}$ Harper "The Evolution of the English Building Regulations 1840-1914" p 44

\begin{tabular}{|l|c|c|c|c|c|}
\hline House Sort & Cellar & 1 storey & 2 storeys & 3 storeys & 4 storeys \\
\hline 1st (Houses fronting By Streets \& Lanes) & $61 / 2 \mathrm{ft}(2 \mathrm{~m})$ & $9 \mathrm{ft}(2.7 \mathrm{~m})$ & $9 \mathrm{ft}(2.7 \mathrm{~m})$ & & \\
\hline 2nd (Streets, Lanes of Note \& River Thames & $61 / 2 \mathrm{ft}(2 \mathrm{~m})$ & $10 \mathrm{ft}(3 \mathrm{~m})$ & $10 \mathrm{ft}(3 \mathrm{~m})$ & $9 \mathrm{ft}(2.7 \mathrm{~m})$ & \\
\hline 3rd (High Streets \& Lanes of Note) & & $10 \mathrm{ft}(3 \mathrm{~m})$ & $10 \frac{1}{2} \mathrm{ft}(3.2 \mathrm{~m})$ & $9 \mathrm{ft}(2.7 \mathrm{~m})$ & $8 \frac{1}{2} \mathrm{ft}(2.6 \mathrm{~m})$ \\
\hline
\end{tabular}

Table 1: "Act for Rebuilding City of London" 1666 (Great Britain Parliament House of Commons p 611).

while in the attic at the centre the $7 \mathrm{ft}(2.1 \mathrm{~m})$ minimum was required but with a minimum side wall height of $3 \mathrm{ft} 6$ in $(1.1 \mathrm{~m})$. The Metropolitan Building Act 1855 continued the $7 \mathrm{ft}(2.1 \mathrm{~m})$ minimum but in the attic $7 \mathrm{ft}(2.1$ $\mathrm{m})$ was only required over half of the area. The London Building Act 1894 had $8 \mathrm{ft} 6$ in $(2.6 \mathrm{~m})$ minimum and in the attic $8 \mathrm{ft}(2.4 \mathrm{~m})$ over at least half the area. The trade-offs being made are clear - lower ceiling heights allow more storeys, more rentable space and increased profits. The incongruity of a habitable room in the main body of a building requiring a fixed height which could be reduced when under a sloping roof, and still retain the same beneficial health consequences was noted in the discussion of the time. ${ }^{4}$

In summary, in London floor-to-ceiling heights in habitable rooms in the houses of the lower and middle classes reduced from $9 \mathrm{ft}$ $(2.7 \mathrm{~m})$ in 1666 to $7 \mathrm{ft}(2.1 \mathrm{~m})$ in 1844

${ }^{4}$ Harper "The Evolution of the English Building Regulations 1840-1914" p 444. increasing to $9 \mathrm{ft}(2.7 \mathrm{~m})$ in 1889 and reducing to $8 \mathrm{ft} 6$ in $(2.6 \mathrm{~m})$ in 1893 . What was happening in the rest of the world by the end of the nineteenth century?

\section{International Minimum Height}

\section{Requirements 1890s-1920s}

In 1892 the National Board of the Fire Underwriters of the United States requested the Department of State to undertake an international survey of fire statistics and building construction. ${ }^{5}$ Published in 1892, the "Special Consular Report" provides information on 113 cities in 29 countries. Information on minimum height requirements for reported for only seven cities $(6 \%)$, and is summarised in Table 2.

Apart from Rouen, which reportedly had minimum height requirements from 1790, ${ }^{6}$ the other examples are from either parts of the

${ }^{5}$ US Fire and Building Regulations in Foreign Countries VIII.

${ }^{6}$ US Fire and Building Regulations in Foreign Countries VIII p 48 . 
United Kingdom, or current or former colonies. Minimum room height ranges from 7 $\mathrm{ft}(2.1 \mathrm{~m})$ in highly urbanised London to $8 \mathrm{ft}$ $(2.4 \mathrm{~m})$ or $9 \mathrm{ft}(2.7 \mathrm{~m})$ elsewhere.

By the 1890s, New Zealand was also starting to include minimum room height requirements in its building bylaws. In the
City of Wellington 1895 Building By-law, the second paragraph of clause 59 "Ventilation Under Floors," deals with height requirements for residential rooms (emphasis added):

Every person who shall erect a new building for residential purposes shall so construct every room intended to be used as a dwelling or sleeping-room, (not being in the attic or roof) so that the same shall be in

\begin{tabular}{|c|c|c|c|c|c|c|}
\hline City & Country & Height & Attic-centre & Attic -side & Attic-average & Other \\
\hline Sydney & Australia & $8 \mathrm{ft}(2.4 \mathrm{~m})$ & $7 \mathrm{ft} 6$ in $(2.3 \mathrm{~m})$ & $3 \mathrm{ft} 6$ in $(1.1 \mathrm{~m})$ & & \\
\hline Melbourne & Australia & $8 \mathrm{ft}(2.4 \mathrm{~m})$ & $8 \mathrm{ft}(2.4 \mathrm{~m})$ & $3 \mathrm{ft} 6$ in $(1.1 \mathrm{~m})$ & & \\
\hline Bombay & India & $8 \mathrm{ft}(2.4 \mathrm{~m})$ & & & $7 \mathrm{ft}(2.1 \mathrm{~m})$ & \\
\hline London & England & $7 \mathrm{ft}(2.1 \mathrm{~m})$ & & & $7 \mathrm{ft}(2.1 \mathrm{~m})^{*}$ & \\
\hline Huddersfield & England & $9 \mathrm{ft}(2.7 \mathrm{~m})$ & & & $7 \mathrm{ft}(2.1 \mathrm{~m})^{*}$ & $8 \mathrm{ft} 6$ in $(2.6 \mathrm{~m})^{\wedge}$ \\
\hline \begin{tabular}{|l|} 
Glasgow \\
\end{tabular} & Scotland & $9 \mathrm{ft}(2.7 \mathrm{~m})$ & & & $8 \mathrm{ft}(2.4 \mathrm{~m})^{*}$ & \\
\hline Rouen & France & $8 \mathrm{ft} 6$ in $(2.6 \mathrm{~m})$ & $7 \mathrm{ft} 6$ in $2.3 \mathrm{~m})$ & & & \\
\hline
\end{tabular}

* height over "not less than" half area; ^ room below or partially below ground level

Table 2: International Minimum Height Reauirements for Habitable Rooms 1892

\begin{tabular}{|c|c|c|c|c|c|}
\hline City/Source & Year & Height & Attic-centre & Attic-side & Attic: other \\
\hline Wellington City Building By-Law* & 1895 & $9 \mathrm{ft}(2.7 \mathrm{~m})$ & $8 \mathrm{ft}(2.6 \mathrm{~m})$ & $3 \mathrm{ft} 6$ in $(1.1 \mathrm{~m})$ & \\
\hline City of Dunedin By-Laws ${ }^{\sharp}$ & 1912 & $10 \mathrm{ft}(3 \mathrm{~m})$ & $9 \mathrm{ft}(2.6 \mathrm{~m})$ & $3 \mathrm{ft} 6$ in $(1.1 \mathrm{~m})$ & \\
\hline Dept. of Health Suggestions for By-laws^ & 1912 & $8 \mathrm{ft} 6$ in $(2.6 \mathrm{~m})$ & & $5 \mathrm{ft}(1.5 \mathrm{~m})$ & $9 \mathrm{ft}(2.7 \mathrm{~m})$ over $1 / 2$ \\
\hline Auckland City By-Laws Nos. $1 \& 2^{* *}$ & 1925 & $9 \mathrm{ft}(2.7 \mathrm{~m})$ & & $5 \mathrm{ft}(1.5 \mathrm{~m})$ & $8 \mathrm{ft}(2.6 \mathrm{~m})$ over $1 / 2$ \\
\hline Otago Counties Joint By-Law ${ }^{\# \#}$ & 1927 & $8 \mathrm{ft}(2.6 \mathrm{~m})$ & & & $8 \mathrm{ft}(2.6 \mathrm{~m})$ over $2 / 3$ \\
\hline Nelson Counties Joint By-Law ${ }^{\wedge \wedge}$ & 1934 & $8 \mathrm{ft}(2.6 \mathrm{~m})$ & & & $8 \mathrm{ft}(2.6 \mathrm{~m})$ over $1 / 2$ \\
\hline NZSS 95 Part VIII*** & 1943 & $8 \mathrm{ft}(2.6 \mathrm{~m})$ & & $5 \mathrm{ft}(1.5 \mathrm{~m})$ & $8 \mathrm{ft}(2.6 \mathrm{~m})$ over $1 / 2$ \\
\hline Housing Improvement Regulations ${ }^{\sharp \# \#}$ & 1947 & $8 \mathrm{ft}(2.6 \mathrm{~m})$ & & $5 \mathrm{ft}(1.5 \mathrm{~m})$ & $8 \mathrm{ft}(2.6 \mathrm{~m})$ over $1 / 2$ \\
\hline NZSS 1900 Chapter $4^{\wedge \wedge \wedge}$ & 1964 & $8 \mathrm{ft}(2.6 \mathrm{~m})$ & & $7 \mathrm{ft}(2.1 \mathrm{~m})$ & $8 \mathrm{ft}(2.6 \mathrm{~m})$ over $1 / 2$ \\
\hline
\end{tabular}

* Wellington (N.Z.) City Council Wellington City Council: Building By-Law. 1895 Clause 59; * Dunedin (N. Z.) City Council Corporation of the City of Dunedin By-Laws Clause 203; ^ Department of Public Health, Hospitals and Charitable Aid Suggestions for By-Laws Clause 14; **Auckland City The Auckland City By-Laws Nos. 1 \& 21925 Clause 148; \#\# Otago Counties Otago Counties' Joint By-Law 1927 p 99 , Clause 128; ^^ Nelson Counties Nelson Counties Joint By-Law 1934 p 98, Clause 146(2); *** NZSI NZSS 95 New Zealand Standard Code of Building ByLaws. Part VIII - Residential Buildings Clause 807; \#\#\# Government of New Zealand Housing Improvement Regulations 1947 reg. 10; ^^^ NZSI NZSS 1900 New Zealand Standard Model Building Bylaw: Chapter 4:1964 Construction Residential Buildings Clause 4.6.1.

Table 3: NZ Minimum Heights for Habitable Rooms 1895-Present every part not less than nine feet $(2.7 \mathrm{~m})$ in height from the floor to the ceiling, and so that every room intended to be used as aforesaid in the attic or roof shall be not less than eight feet $(2.4 \mathrm{~m})$ in height from the floor over one half the superficial area of such room, and shall have not less than three feet six inches $(1.1 \mathrm{~m})$ of straight wall before slope of roof commences.

Table 3 summarises NZ minimum height requirements for habitable rooms from 1895 to the present day. The Housing Improvement Regulations 1947 (amended 1975) were made under the Housing Improvement Act 1945. The Act permitted the making of regulations to deal with construction, condition, situation, drainage, sanitation, ventilation, lighting, cleanliness, repair, wholesome water, protection from damp and: "4(f) The dimensions, cubical content, and height of rooms of houses." The 1947 Regulations remain in force even though "oft forgotten."7

The left two columns give the document name and publication year. The "Height" is the minimum acceptable height in a habitable room, unless an attic room. For attic rooms, the three right columns give the centre height and the minimum wall height permitted to be included in the habitable space, with "Other" providing the relative area i.e. the attic room

${ }^{7}$ BRANZ Ltd "BRANZ Guideline March 2017" p 3. 
height must be a minimum of $9 \mathrm{ft}(2.7 \mathrm{~m})$ over one half or two thirds of the floor area. It should be noted that NZSS 1900 Chapter 4 1964 has a more constrained area than the Housing Improvement Regulations 1947 due to the increased side wall height.

\section{NZSS 95 Building Code Committee Light Wood Buildings}

A review of the "Building Code Committee Light Wood Buildings" minutes for the development of NZSS 95 Part VIII found it was based on the then current review of the Wellington City Corporation "Flats and Apartments House Bylaw," combined with the current Auckland City Bylaw and the 1925 "Model By-Laws Under the Health Act 1920, Relating to Dwellings and Buildings for Human Habitation" prepared by the Department of Health. ${ }^{8}$ It has not been possible to obtain a copy of these model bylaws, although the recommendations of the earlier 1912 "suggestions" are included in Table 3.

Membership of the committees developing NZSS 95 included Alexander R Entrican, an

\footnotetext{
${ }^{8}$ Meeting No. 1, 28 April 1938, NZSI Building Code Committee Light Wood Buildings p 2.
}

engineer with the State Forest Service. Entrican had previously been involved in the setting up and running the 1924 conference on the use of timber in building construction. ${ }^{9}$ Early preparation for that conference had involved the surveying of all New Zealand local authorities to determine their current bylaws relating to the use of timber in buildings, ${ }^{10}$ and this process was repeated for NZSS 95. ${ }^{11}$ As a result, even lacking the original building bylaws, it is possible to compare the evolution of room height requirements from 1924 to 1938.

The 1924 survey reported minimum habitable room heights for 19 local authorities out of the $37(51 \%)$ surveyed, while the 1938 survey had 61 out of $84(74 \%)$. Only 10 local authorities reported minimum heights in both surveys. Table 4 gives count and percentage by height. Although the median $9 \mathrm{ft}(2.7 \mathrm{~m})$, minimum 8 $\mathrm{ft}(2.4 \mathrm{~m})$ and maximum $10 \mathrm{ft}(3.0 \mathrm{~m})$ apply for

${ }^{9}$ NZSSFS Recommendations of Building Conference Relating to the Use of Timber in Building-Construction; Isaacs

"'Recommended Minimum Requirements for Small Dwelling Construction"'" II:781-786.

${ }^{10}$ NZSFS Digest of New Zealand Local Body By-Laws Which Concern the Use of Timber in Buildings. ${ }^{11}$ NZ State Forest Service for New Zealand Standards Institute. Digest of Local Body By-Laws Relating to the Use of Timber in Buildings.

\begin{tabular}{|l|rr|rr|}
\hline & $\begin{array}{r}\text { Dwelling } \\
1924(19)\end{array}$ & $\begin{array}{r}\text { Dwelling } \\
1931(62)\end{array}$ & 1924 & 1931 \\
\hline $8^{\prime}(2.4 \mathrm{~m})$ & 2 & 24 & $11 \%$ & $39 \%$ \\
$8^{\prime} 6^{\prime \prime}(2.6 \mathrm{~m})$ & - & 7 & $0 \%$ & $11 \%$ \\
$9^{\prime}(2.7 \mathrm{~m})$ & 13 & 26 & $68 \%$ & $42 \%$ \\
$9^{\prime} 6^{\prime \prime}(2.9 \mathrm{~m})$ & 1 & 4 & $5 \%$ & $6 \%$ \\
$10^{\prime}(3.0 \mathrm{~m})$ & 3 & 1 & $16 \%$ & $2 \%$ \\
\hline TOTAL & 19 & 62 & $100 \%$ & $100 \%$ \\
\hline
\end{tabular}

Table 4: NZ Local Authority Floor to Ceiling Height Counts from 1924 and 1931 Surveys

both surveys, the average shifted from just over $9 \mathrm{ft}(2.8 \mathrm{~m})$ in 1924 to $8 \mathrm{ft} 6$ in $(2.6 \mathrm{~m})$ in 1931.

When comparing the 19 individual local authorities across the 1924 and 1931 surveys, five $(26 \%)$ made no change, four $(21 \%)$ reduced the height while the other $10(53 \%)$ no longer had any height requirement by 1931 (including Wellington and Dunedin).

As shown in Table 3, when the minimum habitable room height was implemented in NZSS 95 Part VIII, the value of $8 \mathrm{ft}(2.4 \mathrm{~m})$ was used, and this was the value used for both the 1947 Housing Improvement Regulations and the 1964 replacement NZSS 1900 Chapter 4.

\section{Discussion}

Establishing minimum room heights for 
habitable rooms does not fit neatly with the many other issues controlled through building bylaws. Roger Harper, in examining the development of English building regulations from 1840 to 1914, concluded:

The geometric construction of a zone of open space outside a window is a crude mechanical device to achieve a very subjective control of the ventilation of a room, as is the control on the height of a room, unrelated to either area or cubic size. We can attribute these types of regulations to the period immediately after 1840 . They were an obvious and convenient device. ${ }^{12}$

This device was transported to the colony of New Zealand. When health inspectors were faced with poor living conditions relating to overcrowding and the inadequate provision of fresh air, one obvious solution was to mandate room height and provision for ventilation.

By why would ventilation relate so closely to health? It is suggested that even though obsolete by the mid-1800s, the link is through the miasma theory of disease. The miasma theory was summarised by Vitruvius in the first century: "Cold winds are disagreeable, hot winds enervating, moist winds

\footnotetext{
${ }^{12}$ Harper "The Evolution of the English Building Regulations 1840-1914" p 50.
}

unhealthy."13

The theory was still prevalent in the early nineteenth century, for example with "noxious and prejudicial effluvium" considered to be the origin of decay. ${ }^{14}$ In order to prevent decay, ventilation had to be provided in a way which ensured no corners of stagnant air remain. ${ }^{15}$ However, while the theory was replaced, the method of dealing with the problems changed but little. For example, when dealing with sub-floor ventilation which is required for the durability of framing timbers, it was not until the 1940s empirical evidence was obtained yet the requirements have remained largely unchanged. ${ }^{16}$

Similar language is to be found in the justification of minimum room heights and the use of opening windows. An 1873 "Manual for Medical Officers of Health" noted that while usual room height varied from $8 \mathrm{ft}$ (2.4 m) (e.g. cottages in the town or country)

${ }^{13}$ Vitruvius et al. Vitruvius: The Ten Books on Architecture p 16, VI 3.1.

${ }^{14}$ Papworth Essay on the Causes of the Dry Rot in Buildings p 45.

${ }^{15}$ Bidlake Dry Rot in Timber p 16

${ }^{16}$ Isaacs "Evolution of Sub-Floor Moisture Management Requirements" p 386. to $12 \mathrm{ft}(3.7 \mathrm{~m})$ (e.g. houses of middle and wealth classes), the mandatory minimum of 7 $\mathrm{ft}(2.1 \mathrm{~m})$ was insufficient for ventilation, health or convenience. ${ }^{17}$ It further recommended that ventilation:

must provide for the removal of the air, heated and deteriorated by the combustion of gas, which will be chiefly in the upper part of the room, and of that which is deteriorated and also slightly heated by the respiration of man, which will be chiefly in the lower part. ${ }^{18}$

This was a very practical reason why room heights should have been higher in earlier years: smell. Candles, oil lamps or town gas in the process of combustion also generated odorous and non-odorous toxic byproducts possibly the reason for the 1666 London rebuilding act to require higher room heights for wealthy houses which would be more likely to have higher levels of illumination. The smell of clothing (before the days of automatic washing machines and clothes dryers), people (before the daily bath or shower), and the smell of mould and decay could all add to creating an unpleasant (if not dangerous) environment.

${ }^{17}$ Smith Manual for Medical Officers of Health pp 37-38. ${ }^{18}$ Smith Manual for Medical Officers of Health $\mathrm{p} 46$. 
The removal of vitiated or consumed air, continued to be the focus of both room height and ventilation requirements. For example, when in response to WWII building material restrictions the Palmerston North City Council decided to permit a reduction in the minimum habitable room height from $9 \mathrm{ft}(2.7 \mathrm{~m})$ to $8 \mathrm{ft}$ $(2.4 \mathrm{~m})$ it was argued:

This does not mean that the standard is lowered-the cubic content and change of air in habitable rooms has been closely guarded. The nearer the top of the ventilating fanlight or sash is to the ceiling the less dead air will be found in any room. ${ }^{19}$

With these issues resolved, although not universally, there is an argument in modern homes that minimum ceiling heights in habitable rooms are no longer required. BRANZ, in 1983, was raising questions as to whether lower room heights would lead to reduced use of materials, reduced space heating energy and reduced construction cost. $^{20}$ In 1990 the Building Industry Commission (BIC) set out its views for the development of the (now) New Zealand Building Code (NZBC), concluding its primary purpose should be to "preserve the health and safety of people," taking into

\footnotetext{
19 "Building Activity" p 4.

${ }^{20}$ Fowkes "Room Height" pp 1-2.
}

account amenity with potential adverse mental and physical consequences but not for: "protection of economic interests ... since value and quality can be supplied through forces of the market."21 The BIC expected the Housing Improvement Regulations 1947 to be subsumed within the NZBC, ${ }^{22}$ but this did not occur and as has been discussed, they remain in place.

Do the variety of dimensions (see Table 2, Table 3 and Table 4) for New Zealand and internationally mean there is lack of "evidence" for the minimum habitable room heights? And if there is a lack of evidence, are habitable room minimum heights no longer required? As with many aspects of the interaction of people with buildings, there is no "perfect" answer, and arguments could be put forward to remove or retain these requirements.

A better question might be - has the minimum habitable room height created a positive outcome? In this the answer is strongly positive. The rush to build ever smaller rental dwellings provides strong

${ }^{21}$ BIC Reform of Building Controls v 1 p 41.

${ }^{22}$ BIC Reform of Building Controls v 1 p 92. evidence in favour of this approach. Newspaper reports of minuscule apartments lacking space and natural ventilation suggest that even the existing mandatory requirements are not always followed. ${ }^{23}$ The move to rational, evidence based new building controls must not be allowed to leave behind those aspects of historic codes which while not precisely measurable are environmentally supportive.

${ }^{23}$ Keogh "Tiny Auckland "apartment" Too Small to House Anyone, Investigation Finds" n.p. 


\section{REFERENCES}

Auckland City The Auckland City By-Laws Nos. 1 \& 21925 Auckland: 1925.

Bidlake, W.H., Dry Rot in Timber London: B.T. Batsford, 1889.

Building Industry Commission (BIC) Reform of Building Controls: Report to the Minister of Internal Affairs Wellington N.Z.: Building Industry Commission, 1990. 2 vols.

BRANZ Ltd "BRANZ Guideline March 2017" Wellington: BRANZ Ltd, 2017. https://www.branz.co.nz/pubs/guideline/

"Building Activity" Manawatu Standard (30 June 1945): 4.

Department of Public Health, Hospitals and Charitable Aid Suggestions for By-Laws Suitable for Adoption in Counties, Town and Road Districts Wellington N.Z.: Government Printer, 1912. Alexander Turnbull Library, MS-Papers-1293-047/1

Dunedin (N. Z.) City Council Corporation of the City of Dunedin By-Laws Dunedin, N.Z.: Fergusson and Mitchell Ltd. Printers, 1912.

Fowkes, Roger "Room Height" BUILD (April 1983): 1-2

Government of New Zealand Housing Improvement Regulations 1947 http://www.nzlii.org/nz/legis/num_reg/hir1947355/

Great Britain Parliament House of Commons An Act for Rebuilding the City of London 1666 (18 \& 19 Car II cap. 8) pp 603-612 https://archive.org/details/statutes_of_the_realm_5

Harper, Roger Henley "The Evolution of the English Building Regulations 1840-1914" (unpublished PhD, University of Sheffield, 1978) <http://etheses.whiterose.ac.uk/10303/> [accessed 5 July 2016]

Isaacs, Nigel P. "Evolution of Sub-Floor Moisture Management Requirements in UK, USA and New Zealand 1600s to 1969" International Journal of Building Pathology and Adaptation, (2019) 37(4):366-394 https://doi.org/10.1108/IJBPA-06-2018-0052.

Isaacs, Nigel P. "'Recommended Minimum Requirements for Small
Dwelling Construction" - a Forgotten Ancestor of the Modern USA Building Code" Building Knowledge, Constructing Histories, ed. by Ine Wouters, Stephanie Van de Voorde, Inge Bertels, Bernard Espion, Krista De Jonge, and Denis Zastavni (presented at the 6th International Congress on Construction History (6ICCH), Brussels, Belgium: CRC Press, 2018), II, 781-786.

Keogh, Brittany "Tiny Auckland "apartment" Too Small to House Anyone, Investigation Finds" Stuff (14 December 2019) https://www.stuff.co.nz/business/property/118144194/tiny-aucklandapartment-too-small-to-house-anyone-investigation-finds

Nelson Counties, Nelson Counties Joint By-Law 1934 (Counties of Waimea, Takaka, Collingwood and Murchison) 1934.

New Zealand Standards Institute (NZSI). Building Code Committee Light Wood Buildings (1937-38) (New Zealand Standards Institute, 1937). Archives New Zealand Wellington, ADSQ Series 17639 Group F1 Item $563 / 45 / 119 / 2$ Part 1

New Zealand Standards Institute (NZSI). NZSS 95 New Zealand Standard Code of Building By-Laws. Part VIII. Residential Buildings Wellington N.Z.: New Zealand Standards Institute, 1943.

New Zealand Standards Institute (NZSI) NZSS 1900 New Zealand Standard Model Building Bylaw: Chapter 4:1964 Construction Residential Buildings (Incorporating Amendments 1 \& 2) Wellington N.Z.: New Zealand Standards Institute, 1973.

New Zealand State Forest Service (NZSFS). Digest of New Zealand Local Body By-Laws Which Concern the Use of Timber in Buildings. 1924, Archives New Zealand, Wellington, ADSQ 17639 F1 W3129/368 SP 03.03

New Zealand State Forest Service (NZSFS) Recommendations of Building Conference Relating to the Use of Timber in Building-Construction. State 
Forest Service Circular 14. Wellington N.Z.: Government Printer, 1924.

New Zealand State Forest Service for New Zealand Standards Institute.

Digest of Local Body By-Laws Relating to the Use of Timber in

Buildings. 1938, Archives New Zealand, Wellington, ADSQ 17639 F1

563/45/119/2 Part 1

Otago Counties Otago Counties' Joint By-Law 1927 (Counties of Waitaki, Waihemo, Waikouaiti, Maniototo, Vincent, Lake, Tuapeka, Clutha, Bruce and Taieri), 1927.

Papworth, John Buonarotti, Essay on the Causes of the Dry Rot in Buildings: Contained in a Series of Letters Addressed to George Ernest James Wright, Esq.: Including Some Observations on the Cure of the Dry Rot, and on the Admission of Air into the Parts of Buildings Affected by That Disease London: John Papworth, 1803. https://archive.org/details/b22415476 Smith, Edward Manual for Medical Officers of Health London: Knight \& Co., 1873. http://archive.org/details/b21931732

Smith, T. Roger "The Metropolitan Building Act - [paper read to] Architectural Association, 17 March 1876 [Part II]" The Builder (25 March 1876): 279-280.

United States (US) Fire and Building Regulations in Foreign Countries., House of Representatives: Special Consular Reports, 52nd Congress, 2nd Session. Washington, D.C.: Bureau of Statistics, Department of State, 1892, VIII (MISC. Doc. No. 111) https//catalog.hathitrust.org/Record/011977202

Vitruvius Pollio, Marcus, Morris Hicky Morgan, and Herbert Langford Warren Vitruvius: The Ten Books on Architecture Cambridge, Massachusetts: Harvard University Press (Dover Publications Ltd), 1914.

Wellington (N.Z.) City Council. Wellington City Council: Building By-Law. 1895 Wellington N.Z.: City of Wellington, 1895. 